\title{
Old Wisdom: The Highly Relevant Lexicographical Knowledge Obtainable from a Specialized Dictionary from $1774^{*}$
}

\author{
Sven Tarp, Department of Afrikaans and Dutch, University of Stellenbosch, \\ Stellenbosch, South Africa and Centre for Lexicography, \\ Aarhus University, Aarhus, Denmark (st@asb.dk)
}

\begin{abstract}
There is little doubt that lexicography has experienced important progress during the years, especially when one compare the lexicographical works from the various centuries. However, history should not be viewed as an ever-growing progress but as a process with its ups and downs. In this respect, some old lexicographical works, especially from the Age of Enlightenment, are in some aspects extremely advanced even compared with present-day dictionaries. Malachy Postlethwayt's Universal Dictionary of Trade and Commerce from 1774 is one such example. The article provides a general presentation of this rare and interesting dictionary which was published in various editions in the 18th century. The presentation includes a detailed description of the objective, functions, structure, and content of this impressive work. The article then focuses on its cognitive and operative functions, and the way they are integrated into one and the same reference work. Upon this basis, the article shows how modern lexicography can use past experiences in order to meet the real and practical needs of present-day users.
\end{abstract}

Keywords: LEXICOGRAPHY, HISTORICAL LEXICOGRAPHY, FUNCTION THEORY, OPERATIVE FUNCTIONS, COGNITIVE FUNCTIONS, DICTIONARIES OF ECONOMICS, INTERDISCIPLINARY VOCATION OF LEXICOGRAPHY, INFORMATION TOOLS

Opsomming: Ou wysheid: Die hoogs tersaaklike leksikografiese kennis bekombaar uit 'n gespesialiseerde woordeboek uit 1774. Daar is min twyfel dat die leksikografie belangrike vooruitgang deur die jare ondergaan het, veral wanneer 'n mens leksikografiese werke uit die verskillende eeue vergelyk. Geskiedenis moet egter nie gesien word as 'n steeds groeiende vooruitgang nie, maar as 'n proses met sy wisselvallighede. In dié opsig is sommige ou leksikografiese werke, veral uit die Eeu van Verligting, in sommige aspekte uiters gevorderd, selfs vergeleke met die hedendaagse woordeboeke. Malachy Postlethwayt se Universal Dictionary of Trade and Commerce van 1774 is een so 'n voorbeeld. Die artikel verskaf 'n algemene

* This article was presented as a paper at the Seventeenth Annual International Conference of the African Association for Lexicography (AFRILEX), which was hosted by the Department of African Languages, University of Pretoria, Pretoria, South Africa, 2-5 July 2012. 
bekendstelling van hierdie seldsame en interessante woordeboek wat in verskillende uitgawes in die 18de eeu gepubliseer is. Die bekendstelling sluit 'n uitvoerige beskrywing van die doel, funksies, struktuur en inhoud van hierdie indrukwekkende werk in. Die artikel fokus daarna op sy kognitiewe en operatiewe funksies, en die manier waarop hulle in een en dieselfde naslaanwerk geïntegreer is. Op grond hiervan toon die artikel hoe die moderne leksikografie vroeëre ervaring kan gebruik om aan die werklike en praktiese behoeftes van hedendaagse gebruikers te voldoen.

Sleutelwoorde: LEKSIKOGRAFIE, HISTORIESE LEKSIKOGRAFIE, FUNKSIETEORIE, OPERATIEWE FUNKSIES, KOGNITIEWE FUNKSIES, EKONOMIEWOORDEBOEKE, INTERDISSIPLINÊRE ROEPING VAN DIE LEKSIKOGRAFIE, INLIGTINGSGEREEDSKAP

\section{Introduction}

There is little doubt that lexicography, both as a practice and a theory, has experienced important progress during the years, especially when one compares the lexicographical works from the various centuries. However, history - including lexicographical history - should not be viewed in a perspective of ever-growing progress but as a process with its ups and downs. The above statement should therefore not be regarded as something absolute and rigid, especially not because there are important exceptions to this general rule to be found in various lexicographical works, especially those under influence of the Age of Enlightenment which, in some aspects, are extremely advanced even compared with present-day dictionaries.

In the Age of Enlightenment, i.e. only a few hundred years ago, lexicography was much more a vocation than a profession. Many dictionaries from that period, both famous ones and long forgotten ones, were compiled by people who were paid nothing or very little for their efforts; they simply felt the compulsion to make them. They were people who did not need to carry out any sophisticated user research; in most cases they knew their future users personally, they knew their specific problems and needs, and often they had experienced the same kinds of problems and needs themselves. They were often practical people: the captain who compiled a dictionary in order to allow his officials, and often also himself, to communicate and solve technical and commercial problems when they entered a harbour in a distant country; the priest who wrote a small glossary to assist his simple-minded confirmation students when they had problems understanding difficult words and expressions used in the catechism; the missionary who produced bilingual dictionaries in order to spread the evangelism and preach it in "exotic" countries and languages, etc. There were also great thinkers like Diderot and d'Alembert, who were convinced that science and enlightenment communicated in an easily accessible way would change the world for the better; there were scholars like Samuel Johnson who simply wanted to ascertain the purity and standard of English and assist his fellow countrymen in improving their English skills.

There were a lot of people, many of whom were industrious, visionary, and innovative authors who did not pay much attention to established con- 
ventions within a field that was still not generally known as lexicography. They were not afraid of experiments and innovations. They took practical decisions and opted for practical solutions to the problems they knew so well. When they compiled dictionaries for the people whom they knew personally, they simply used the forms, methods, and techniques which they considered most appropriate to solve problems which they frequently had experienced in their own life. Sadly enough, this lexicographical spring was followed, not by a warm and sunny summer, but by a cold winter called romanticism which killed many of the seeds planted by the previous generations and left them, so to say, to "the gnawing criticism of the mice". In this way, many valuable experiences and innovations were condemned to an anonymous existence on the dusty shelves of old libraries.

Malachy Postlethwayt's The Universal Dictionary of Trade and Commerce is one such example. The full title of this specialized dictionary - which is in fact more a narrative than a title (see the literature list) - provides immediate information about its content and its usefulness for the potential users. It was first published in London in instalments between 1751 and 1755 and later as a two-volume book in three other editions, in 1757, 1766, and 1774. As far as it has been possible to investigate, the dictionary is not mentioned in any recent literature on lexicography, not even in the volume on Specialized Dictionaries in the History of English Lexicography (Cowie 2009), nor in any of the relatively few contributions on historical lexicography published in Lexikos, Lexicographica, International Journal of Lexicography and other journals of lexicography.

By contrast, Postlethwayt has been briefly presented in various British bibliographies, e.g. Chalmers (1816) and Hewins (1895). And to this should be added that Postlethwayt and his work have been discussed several times by a number of experts in economics and economic history, among them Marx (1867), Johnson (1965), Groenewegen (2004), Mankin (2008), and Besomi (2011). These researchers, however, have obviously not analysed the dictionary from a lexicographical perspective but from the point of view of economics, just as various linguists frequently analyse some specific types of dictionaries from the point of view of their own discipline.

The following contribution will try to remedy this omission, not because Postlethwayt's dictionary surpasses other economic dictionaries from the same period, but because Postlethwayt - just like Samuel Johnson seven years before the publication of A Dictionary of the English Language - also published a dissertation about the dictionary he was working on, cf. Postlethwayt (1749). This dissertation - together with the Introduction in the dictionary - provides a rare insight into the author's motivations and own ideas about the content and structure of his brainchild.

\section{Who was Malachy Postlethwayt?}

Malachy Postlethwayt (1707-1767) was a British economist and publicist of cer- 
tain reputation in his epoch; in fact, his writings are claimed to "have exerted a good deal of influence on the trend of British economic thought", cf. Johnson (1965: 185). He was the author of a number of essays on trade and commerce, but his most noted work is undoubtedly The Universal Dictionary of Trade and Commence, to which "he devoted twenty years", cf. Hewins (1895: 219).

Apart from his publications, little is known about Postlethwayt's life, family, and social position. In his biography, Chalmers (1816: 219) provides the following details:

\begin{abstract}
He was born about the year 1707 but where, of what parents, or how educated, we have not discovered. In the introductory discourse to his work entitled Great Britain's True System, he informs us, that nature having given him a very tender and weak constitution, he studiously declined and avoided, as much as he could, every degree of public life, as being inconsistent with, and indeed destructive of, that small snare of health which he had several years enjoyed, and which his studies had not mended and yet he preferred the studious life, as being more independent, He complains, however, of want of encouragement; and "humbly hopes that some people will be candid and ingenuous enough to think that he has a right to be treated upon a footing something different from that of an upstart idle chemist or projector, who has never given proof of any talents that might deserve the public regard and attention." Whether this complaint was redressed, we know not. He died Sept. 17, 1767, and probably not in very opulent circumstances, as he was buried in Old-street church-yard. The coffin, at his own request, was filled with unslacked lime.
\end{abstract}

If this is true, Postlethwayt seems to be one of the many lexicographers who got more fame than money for their efforts. In addition, the British economist has been criticised for being a plagiarist. According to Johnson (1965: 205), his dictionary included "ideas taken from fifty other past or contemporary writers" as well as "practically all" of the Essai sur la nature de commerce en général (Essay on the Nature of Commerce in General) published by Richard Cantillon in 1755. However, in the opinion of Groenewegen (2004: 999), "this accusation has been greatly exaggerated".

The discussion of plagiarism will be left to the experts in the history of economics. Apart from the fact that no copyright regulations existed in the 18th century, in a lexicographical perspective it is not so relevant if a dictionary is the brainchild of the author himself, or if it has been copied from other sources. Most important for a lexicographical work is that it serves its purpose and meets the needs of its genuine end users. It should never be forgotten that the world's greatest dictionary ever, the Chinese Yongle Dadian of a total of 11,095 volumes, was partially copied from a large number of already existing books whose content, in this way, was made more easily accessible.

Also important to note about Postlethwayt is "his greater interest in political problems; his more intense economic nationalism", cf. Johnson (1965: 402). This political interest and "economic nationalism" were expressed in various ways, first of all in the fact that Postlethwayt's major objective with his diction- 
ary was to strengthen and raise the British Empire, an objective that he openly stated both in his plan for the dictionary, cf. Postlethwayt (1749), and in his Introduction to its fourth edition, cf. Postlethwayt (1774: v):

The great end aimed at by the author is to promote and advance, to the utmost of his abilities, the commercial prosperity and happiness of the British empire, and her colonies and plantations in America.

Postlethwayt's political and economic nationalism - today it would be called colonialist and imperialist ideas - also had other serious implications. During his life he was considered by many to be a paid agent of the Royal Africa Company. Nothing was ever proven but there is no doubt that he was a dedicated propagandist for the Company's mercantilist interests, which he defended and promoted in some of his publications, among them The African Trade, the Great Pillar and Supporter of the British Plantation Trade in North America (Postlethwayt 1745). In this essay he supported British expansion through trade with Africa and the colonies, and promoted the importance of slavery for British commerce and industry.

Whether an agent or not, the conclusion is that Postlethwayt was a child of his time, an intellectual who, like many other British, each of them in their own way, contributed to the colonialist destruction of Africa. In this respect, it is important to emphasize that the author's political, economic, commercial, and other ideas reflected in the dictionary are of purely historical interest; it is not from these outdated ideas that present-day lexicography may learn something from Postlethwayt, but from the way he prepared his data and transmitted his message by means of a dictionary.

\section{Objectives of the dictionary}

The Universal Dictionary of Trade and Commerce was partially a translation of a similar French work, Jacques Savary des Bruslons' Dictionnaire universel de commerce, first published in 1723 and subsequently in various editions and translated, apart from the English version, into German as Allgemeine Schatz-Kammer der Kaufmannschaft (1741-1743), and Italian as Dizionario di commercio dei signori Fratelli Savary (1770), cf. Besomi (2011: 28).

In 1749, i.e. two years before the appearance of the first instalment of his dictionary, Postlethwayt published a short dissertation on "the Plan, Use, and Importance" of the dictionary. In the title of this 52-page booklet, the author openly states that it will be translated from the French original, compiled by "the late Celebrated Mons. Savary, Inspector-General of the Manufactures of the Custom-House of Paris". However, he also adds that it will contain "considerable Additions and Improvements" from his own hand, and that it is "Addressed to the Nobility, Gentry, Merchants, and Traders of Great Britain" with the objective to "more particularly accommodate the Fame to the Trade and Navigation of the British Empire". 
As to the important question of the sources to the wealth of a nation, later treated with much more scientific rigour by Adam Smith (1776), Postlethwayt (1749: 1) writes:

It is allowed on all hands, that agriculture and commerce nourish and enrich a nation.

In this respect, the author deplores that the British Empire suffered from some serious problems. He explains how the various people engaged in trade and commerce in one way or another - i.e. "Statesman, the Senator, the private Gentleman, the Trader, or the Manufacturer" - frequently do not have a "satisfactory knowledge of Facts in complicated matters of a commercial nature", and that the acquisition of this knowledge is not an easy matter, cf. Postlethwayt (1749: 2):

Foreign and domestic trade admitting of so infinite variety of matter, and the knowledge communicated to the world, by those skilled and experienced therein, being scattered in an infinity of volumes, it is no easy matter to have immediate recourse to what may be occasionally requisite.

For Postlethwayt (1749: 2), the solution to this serious problem for the British trade and commerce, and eventually for the British Empire, has to be found in lexicography:

A subject of this extensive nature therefore being reduced to the form of a Dictionary, for alphabetical reference, seems the most naturally adapted to answer these desirable purposes, and especially so, as the compilers can have no motive to deceive.

As an example of the practicability of this idea, he refers explicitly to Savary des Bruslons' Dictionnaire universel de commerce, a "celebrated work" which has proven "how far an universal knowledge of commerce is capable of being reduced into the like form". Postlethwayt (1749: 3) then lets this work "speak for itself" in order to:

communicate, not only the original Plan, but to give a succinct account of such additional matter, as is proposed to be incorporated throughout the whole, in an english dress, to the end that the fame may be more peculiarly adapted to the state of the trade and navigation of the british empire.

In these few lines we acquire a fairly good idea of the principal intention of Postlethwayt's dictionary:

- His main objective is to strengthen the British Empire which, according to him, is nourished by its agriculture and commerce.

- However, he has observed a serious problem, namely that the relevant people do not possess satisfactory knowledge of facts regarding trade and commerce, and that these people, in addition, have neither time nor 
the possibility to obtain this knowledge because it is scattered in an infinity of volumes.

- For the benefit of the Empire and its commerce, he therefore sets himself the task of solving the problem by means of an alphabetically structured dictionary providing access to the required information.

In this way, the objective of the dictionary, its target user group, the users' needs, and the context where the needs may occur, are defined by the author much better than in many modern dictionaries where publicity has taken over; or they seem to be so defined, because Postlethwayt has more surprises up his sleeve.

\section{The fourth edition}

In 1774, seven years after Postlethwayt's death, the fourth edition of his Universal Dictionary appeared. Nothing is said about the author and his fate, or why it was not published before, but both the title and the content suggest that Postlethwayt worked on the dictionary after the Peace Treaty in 1763, probably until 1767 when he suddenly died "as he had often wished", cf. Chalmers (1816: 220). The fourth edition is the most developed and the one to which Postlethwayt contributed most of his own material; it is generally this edition that is discussed by economists and historians, and it will therefore also be the one to be dealt with in what follows.

The fourth edition of The Universal Dictionary of Trade of Commerce consists, like the previous editions, of two volumes, each of which having the considerable size of $44 \times 29 \times 17 \mathrm{~cm}$. It comprises five main sections:

- Dedication

- Introduction, including "a General Idea of the Content"

- Preliminary Discourse the First

- Preliminary Discourse the Second

- The Dictionary as such (without pagination)

The dedication, dated February 10, 1766, i.e. a year and a half before the author's death, is addressed to the Mayor of the City of London as well as to the city's merchants and tradesmen who, according to the author, "constitute the very active Soul of the Commerce of the whole British State". The entire tone of this dedication reflects the "want of encouragement" mentioned by Chalmers (1816).

The first part of the Preliminary Discourse is Postlethwayt's personal introduction to the subject where he mainly explains "the Present Commercial Grievances" and the deplorable situation in which Britain finds itself according 
to his understanding. The second part of the Preliminary Discourse contains the author's own visions and recommendations on how Great Britain could use the Peace Treaty from 1763 with Spain "to redress the National Grievances represented in the preceding Preliminary Discourse", and make "the Peace of Europe more lasting, and to safe Great Britain the future Expence of engaging in the Continental Wars of Europe", a fact showing how he also intended to use the dictionary as a medium to communicate his personal ideas for exerting influence on political and economic affairs. From a lexicographical perspective, the two parts of the Preliminary Discourse represent, in an embryonic form, a prelude to the systematic introductions included in a number of modern specialized dictionaries, e.g. the Encyclopedic Dictionary of Gene Technology.

It is, however, the Introduction that contains the most interesting comments. Here the author initially presents his dictionary as "the first of its kind that was ever published in Great Britain", and then continues in a far from modest way saying that the previous editions have given it a reputation that makes recommendations almost superfluous (page iii):

Having obtained a reputation for above fourteen years, with those esteemed the best judges in the kingdom, amongst the nobility and gentry; and its credit and character also amongst commercial people of the best understanding, as well merchants as tradesmen, manufacturers and artisans of every respectable rank, render it the less necessary to urge any thing now in its recommendation.

In the Introduction, the author - apart from stating the objective of the dictionary already quoted above - also touches on a topic which permeates the whole dictionary, i.e. the relation to and envy of France; this country is considered not so much an enemy as a competitor who in many respects (law, trade, manufacture, etc.) is doing far better than Britain, and from whom the country and its traders and manufacturers can learn much (page iii):

But the difference between us and France conflicts chiefly in this; that they take no less care in the execution of their laws of trade, than in making them: We are remarkable for good laws, but are shamefully neglectful in their execution. It is not upon this account, that our bakers are suffered to adulterate their bread, to the injury of the public health; and to daily trick the poor in the weight, as well as the rich and poor in the quality of their bread; In France these things are better guarded against.

Anybody who has read novels and social reports from London in the 18th and 19th century will know that the city's bakers continued to adulterate their bread for a long period, and that Postlethwayt's recommendations did not seem to have any notable effect on this regrettable practice. However, from a modern lexicographical point of view, probably the most intriguing particular in the Introduction is that Postlethwayt clearly explains that the dictionary does not only have a cognitive function providing knowledge to its users (page v):

The whole containing a greater fund of commercial knowledge, relating to the 
universal trade and navigation, both practical and political, than ever appeared in any dictionary of commerce, in this, or any other state or empire.

What is really surprising is that the author also conceived the dictionary with an operative function in order to provide its intended user group with various sorts of proposals, recommendations and suggestions to be used in different contexts (page iii):

This work abounds with no small variety of suggestions and intimations for the advancement of numerous branches of the trade and commerce of these kingdoms; which every discerning reader will make his proper use of, either for his own private benefit and advantage, or those of the public. Many manufacturers have wrote letters to the author, returning him their grateful thanks for the services he has laboured to do them; and he has been happily instrumental to set several new manufactures on foot for the public interest.

Operative functions are defined as the lexicographical assistance to users who need "advice and instructions in order to perform any kind of mental or manual action"; cf. Tarp (2008: 185).

It is only during the last five or six years that modern lexicography — and especially the supporters of the function theory - has started discussing these functions and the need to have them covered by various types of dictionaries and other information tools, an idea which has still not been generally accepted by the lexicographical community. For instance, at the Seventeenth International Conference of AFRILEX, held at the University of Pretoria in July 2012, an interesting discussion developed when the French-Danish lexicographer and supporter of the function theory, Patrick Leroyer (2012), presented his vision for a wine dictionary with both cognitive and operative functions, and was then contested by the President of AFRILEX, Gilles-Maurice de Schryver, who claimed that this was not lexicography.

However, returning to Postlethwayt - and the Age of Enlightenment - it will be found that operative functions as defined by the function theory were already an integrated part of lexicography in that period. And the reason for this was that the authors knew that their users demanded this sort of information as it is clearly expressed in the letters from the manufacturers, to which Postlethwayt refers in the above quotation.

\section{The content}

In a spirit typical for the 18th century, Postlethwayt (1749) writes that he has read everything that is worth reading about trade and commerce. In a certain manner it seems that he has not only read "everything", but also put "everything" into his Universal Dictionary, described by Johnson (1965: 188) as a "huge storehouse of economic facts, laws and theory". It is therefore not easy to give a short description of its rich content and structure. 
The dictionary is structured in alphabetically organised articles, some of which contain very short definitions of only a few lines whereas others consist of complex texts of many pages. Many of the articles include long extracts from laws, letters, books, newspapers, and other documents. As a rule these long articles start with a definition, or explanation in a broader sense of the word, then incorporates some extracts from already existing documents, a section called Remarks and sometimes even Additional Remarks added by the author to the various editions. The description of the phenomena is often mixed with Postlethwayt's personal opinions, a detailed explanation of how they are produced and used, as well as recommendations on how to improve their production. The articles frequently contain hand-drawn illustrations, tables, and examples of accounting covering several pages.

The topics treated in the dictionary are of a large variety, in some cases only marginally related to trade and commerce as it is conceived today:

- Trade, commerce, law, and accounting

- Economic theory and practice

- Banking system, money, gold, and silver

- Navigation and naval affairs

- Measures, mathematics, and arithmetic

- Manufacture: silk-worms, brewery, malt, bricklaying, and ship building

- Cities, regions, and countries

- Anecdotes of distinguished citizens of London

- Etc, etc., etc.

The above list could easily be extended to cover several pages. Hewins (1895: 219) considered that Postlethwayt "presented his results without method or conciseness", and in a certain sense he is right. If his dictionary is compared to Savary des Bruslons' Dictionnaire universel de commerce, then it is evident that the latter is better structured and therefore easier to access. For instance, in the French dictionary, the article commerce covers a total of 250 pages and is internally structured with many sublemmata organised in a systematic way. In Postlethwayt's dictionary, the same article covers only about 10 pages, mainly owing to the different language structure, but this and many other articles are either very extensive or constantly interrupted by remarks, additional remarks, and long quotations from laws and other documents as already explained.

If the lexicographical data collected by the compiler are presented "without method or conciseness", as Hewins (1895) claims, this will almost inevitably make it more difficult, or even impossible, for the users to access and find the required data if they do not want to read the whole article from end to end. However, in defence of Posthlethwayt could perhaps be argued that he had to 
systematize his data - which go far beyond those incorporated in Savary des Bruslons' dictionary - in a period when economics had still not developed into a scientific discipline in the modern sense of the word. Adam Smith had not yet published his Wealth of Nations, and David Ricardo and Karl Marx were not yet born or even thought of.

\section{Some articles}

It is impossible to do justice to Postlethwayt's dictionary in the framework of this contribution, but a few articles selected from among the shorter ones may give an idea of its rich content. On the first page under the letter $\mathrm{A}$, we find the article aaggi-doggii:

AAGGI-DOGGII, a Persian word, signifying 'The bitter mountain.' It is so called, on account of being a very dangerous passage for the trading caravans, which travel into Persia, and take their route of Constantinople to Ispahan. It is situated a day's journey from Louri, on the frontiers of Persia, near Chaouqueu. When these caravans are arrived at the pass of this mountain, all the camels and horses are numbered, for each of which the caravan-bachi takes a duty, which he employs partly for the pay of soldiers that guard the caravans, and partly for other small charges: but he detains the greatest part for himself.

It goes without saying that this article is not included in the dictionary in order to inform about geography in general. It has a very practical purpose and is highly relevant for those traders who plan to travel from Constantinople to Ispahan with a caravan, although the information about the caravan-bachi's duty seems more anecdotic than useful for anything but envy. In fact, sometimes Postlethwayt seems to enjoy writing in an anecdotic or even humoristic style as can be seen in the following article:

AMPHISCII. In geography and astronomy, the people who inhabit the Torrid Zone. They are thus denominated, as having their shadow turned sometimes one way, and sometimes another, i.e. at one time of the year to the north, and at another to the south.

As already mentioned, space does not permit the reproduction of the long articles which would illustrate the real complexity and richness of the dictionary; however, a look at the article Lubecker will nevertheless give a rather good idea of the composition of many articles:

LUBECKER.

As of old time the common councils of the free and imperial city of Lubeck, and several other towns upon the North and East Seas, have been in union with divers towns of the United Provinces, for defence of the liberty of trade, and of the rights belonging thereunto: and as now the States-General of the United Provinces, together with the burgomasters and common council of Lubeck, have found it convenient, in the present conjuncture, to treat about 
renewing the aforesaid union and amity, by their respective deputies, who, after several conferences, and reports made, agreed upon the articles following:

I. That this union shall not be offensive, but only for preserving the freedom of commerce, \&c. that the respective citizens and subjects of the union may enjoy the same without molestation, and mutually protect each other; so that the manifold difficulties detrimental to their common trade may be removed. II. $(\ldots)$

Postlethwayt then reproduces the remaining 15 articles composing the whole text agreed upon, and at the bottom of the document he also provides the final statements and signatures:

In witness whereof, two copies of these presents have been made, and confirmed by oath, and sealed with the seals of the States-General, and town of Lubeck, and signed by their respective clerk and syndic, each party retaining one copy. Done in May 1613, and underwritten,

By order of the States-General

Signed AERSSEN,

And by order of the honourable the common council of the town of Lubeck, Signed MARTIN NORDAMUS

Syndic of the Republic of Lubeck.

One may discuss the value of this information, but it could probably have been useful for the British merchants and traders doing business with the Lubeckers on foreign ground. As such, it is very similar to the kind of external data to which the users are frequently referred in modern specialized lexicography, in web-based dictionaries often with direct linking to the respective home pages.

Another article showing how Postlethwayt incorporated various sorts of text and document in his dictionary is letter of credit:

LETTER of CREDIT, is where a merchant, of correspondent, writes a letter to another, requesting him to credit the bearer with a certain sum of money.

\section{Form of a Letter of Credit}

Mr. E.F.

SIR,

London, May 10, 1753

My last to you of the 15th of March, wherein I wrote what was needful, in answer to your's of the 10th of the same month; and this serves chiefly to desire you to furnish and pay unto Mr. C. D. English gentleman, to the value of two thousand crowns, at one or more times, according as he shall have occasion for it, and request the same of you, taking his receipt, of bills of exchange, for the monies which you shall so furnish him with, and put it to my account; and this my letter of credit shall be your sufficient warrant for so doing.

To Mr. E.F. merchant at Madrid Your's, \&c. A. B.

In this rather typical article, the author first provides a small and easily under- 
standable explanation of the term letter of credit, and instead of going into complex details he then furnishes a form which can be directly used by his readers if and when they need to write a letter of credit. This is one of many examples showing that Postlethwayt did not compile his dictionary merely to "describe the words", as a modern linguist would claim, but rather to assist his users and solve their real and practical problems which he undoubtedly knew very well. These users would surely find the above information highly relevant and useful in their daily work.

The article immediately after letter of credit provides another interesting example of how the dictionary was conceived:

LETTER-FOUNDER, He casts types, of letters, for printers: there are but two in London; 'till very lately we had types from Holland; but that excellent artist Mr. Caslon, having excelled all foreign founders, not only furnishes us at home, but sends great quantities abroad.

This is the kind of information which we nowadays would expect to find on the "yellow pages", in a telephone guide, a "who's who", an Internet directory, or a similar printed or electronic information tool conceived for consultation purposes. If the telephone had been invented in Postlethwayt's lifetime, he would probably have furnished the "excellent artist" Mr. Caslon's telephone number as well. When the function theory postulates that the very essence of lexicography is to provide quick and easy access to data from which punctual information can be retrieved, cf. Tarp (2009), its opponents frequently put forward as an argument that the theory does not make a sharp distinction between dictionaries and telephone guides. In fact, they are right, because there is no reason why lexicographical works should not provide this sort of information too. Postlethwayt gave his users the information which he knew that they needed and demanded, and nothing prevents modern lexicography from doing the same and designing integrated information tools, based upon advanced computer and information technologies, with a view to meeting the real and complex needs of the present-day users.

\section{Operative functions}

It has already been stated above that The Universal Dictionary of Trade and Commerce also had an operative function where the author provided "suggestions and intimations", as he called them. There are plenty of examples illustrating how this function was implemented in practice, but only three of them will be discussed here. For instance, under the lemma lead, one will find various sublemmata - or subtitles — such as minium, litharge, burnt lead, white lead or cerusse, saccharum saturni, Remarks, The method of smelting lead ore at the great works with pit-coal, and The method of smelting lead ore with wood fuel, some of which actually contain a sort of receipt as can be seen in the following extract from the article: 
BURNT LEAD

Cut a quantity of this thinnest milled lead that can be got, into small plates, with which fill an earthen vessel that will bear the fire, and, with powder of brimstone, laid layer upon layer; when the sulphur is burnt away, the lead will be in a blackish powder: five ounces of brimstone suffice for half a pound of lead. Stir the matter while on the fire, and, when cold, wash the powder in three of four waters. It is used externally as the litharge: mixed with lard alone, it makes a good unguent for the piles.

Another similar example can be found in the Remarks addressed to the lemma lint where Postlethwayt very politely calls upon "any gentleman who has the conveniency of water for erecting a lint-mill" to go into the lint business:

\section{REMARKS}

The woollen manufacture of England never came to it's perfection 'till the business of the woolstapler came to be a trade; and it must be the same with the linen. - Here is a fine branch of business for any gentleman who has the conveniency of water for erecting a lint-mill; he may either raise lint himself, or buy it in the boon from others, and dress it by his mill for the heckle; he may have his heckles in a convenient house near to it, for dressing and stapling the lint by proper heckles, into fine dressed flax, fine dressed tow, common tow, backings and beards, for the service of the country spinners.

The last illustration of an operative function is taken from the article malt which covers several pages and includes many reflections and recommendations on the making of this important product. The article starts with a traditional definition:

MALT, is barley prepared, to fit it for making a potable liquor called beer or ale.

After this short definition, the article comprises various sections such as Observation on the manner of Malting, Remarks, and An Abstract of the acts of parliament which have been made in relation to Malt. In the first of these sections, and after describing the process of malting, Postlethwayt comments:

This is the general process of malting, wherein almost every maltster has his secret, or particular way of working. But, to render the operation perfect, the following cautions must be observed: (1.) That the barley be newly thrashed, or at least newly winnowed. (2.) That it is not mixed, or made up of different sorts. (3.) That it be not over-steeped in the cistern, or so long as to make it soft. (4.) That it be well drained. (5.) That it is carefully looked after in the wet couch, so as to stop the first tendency of the blade to shooting. (6.) Another caution is, to turn the wet couch inside outermost, if the barley comes, that it shoots more in the middle than on the sides. (7.) To keep it duly turning after it is out of the wet couch. (8.) To give it the proper heating in the dry heap. (9.) To dry and crisp it thoroughly upon the kiln, but without a fierce fire, so as to be several days in drying a kiln of pale malt. And, if these directions be carefully observed, the malt will always be good. 
As it can be clearly seen, the character and structure of this last extract from the Universal Dictionary are very similar to what can be found in modern user guides, instruction manuals, how-tos, etc. It is a proof of the close relationship existing between dictionaries and these types of reference work, a relationship based upon the fact that they are all tools designed to be consulted in order to retrieve punctual information which can subsequently be used for many different purposes. In fact, Postlethwayt's dictionary documents that in the Age of Enlightenment no sharp boundaries existed between the various types of reference works, and that these were occasionally even integrated into one and the same tool.

\section{A living and discussing dictionary}

Reading The Universal Dictionary of Trade and Commerce is far from boring. It was compiled long before the introduction of a stereotype lexicographical style with rigid style sheets and models for the writing of definitions and explanations. In fact, Postlethwayt's dictionary appears as a living and discussing work where the author frequently "interrupts" the presentation in order to provide his own personal opinion on the matter treated, or even to discuss and change his previous opinion. For instance, under the lemma lives [annuities upon lives], an article of several pages, he suddenly considers it necessary to comment on some ideas quoted from another author:

Here I have given the author's proposition and instance in his own words; but, if I may beg leave to express my meaning of them in my way, which, perhaps, may tend to explain and illustrate them, I should say: ...

Although always ready to give his personal opinion, Postlethwayt generally tries not to be unfair to other opinions. For example, a little further on in the above-mentioned article, under the Remarks, he refers to the different opinions expressed by various scholars and provides cross-references to a number of articles where the "substance" of the respective opinions can be found:

\section{REMARKS}

We have judged it necessary to enter so far into this delicate subject, and the objections made to the long embraced hypothesis of the learned Dr. Halley, and the foundations built thereupon by Mr. De Moivre and others (for the objections against the latter are not less weighty than those against the former, though we have not room fully to consider them here) in order to shew the reader, who is desirous to go to the root of this matter, that the works of the learned Weyman Lee, Esq; are well deserving his attentive perusal. There have, indeed, been some objections made to Mr. Lee's essay, but whoever compares them candidly and impartially with the reply that he has made to them, will hardly think, I am at present inclined to believe, that the fundamentals of his reasoning are at all invalidated. However, those who may still be of opinion, that what Dr. Halley, Mr. De Moivre, and Mr. Richards have said, will stand the test, will find the substance thereof in this work, under the articles Annuities and Leases; and the chief 
objections that have been made against them, under the articles Lives, and Mortality [Bill of Mortality].

For the reader's further satisfaction, the following is the connected substance that Mr. Lee endeavours to prove, in opposition to Dr. Halley, Mr. De Moivre, Mr. Richards, and others, on LEASES and LIFE-ANNUITIES.

Postlethwayt is not afraid of admitting that he sometimes changes his opinion on certain questions. As mentioned above, in his dissertation on the plan of the dictionary, cf. Postlethwayt (1749), he expressed the idea that "agriculture and commerce nourish and enrich a nation". This idea is repeated in the fourth edition of his dictionary from 1774 . However, if one consults the article manufacture, one will find the following highly interesting comment:

We begin to be now convinced, that we are nearly as much enriched by the labours of our fellow-creatures, as by the productions of the earth; and, if we have reason to rejoice at the abundance which nature, from year to year, produces for us, we may reap no less reasonable satisfaction from all the variety of employments in human society, and especially by means of our manufactural arts.

Although it may seem a little eclectic, with this comment Postlethwayt is actually taking a big step away from the physiocrats and towards a more modern understanding of the real sources of a country's wealth. The same moderation or change of ideas can be found in the article Africa. Here he still speaks about the "very beneficial traffic" of "gold, teeth, wax, and negroes", but at the same time he puts forward a long-term vision of "laying absolutely aside the slavetrade, and cultivating a fair, friendly, human, and civilized commerce with the Africans", a vision based upon Christian and "civilized" principles and, not to forget, the benefits to trade:

In short, Africa, though a full quarter of the globe, stored with an inexhaustible treasure, and capable, under proper improvements, of producing so many things delightful, as well as convenient within itself, seems utterly neglected by those who are civilized themselves, and its own inhabitants quite unsolicitous of reaping the benefits which nature has provided them. What it affords in its present rude, unimproved state, is solely given up to the gain of others, as if not the people only were to be sold for slaves to their fellow-creatures, but the whole country was captive, and produces its treasures, merely for the use and benefit of the rest of the world, and not at all for their own.

Whether, instead of making slaves of these people, it would not rather become such nations that assume to themselves the name and character of Christians, to give them a relish for the blessing of life, by extending traffic into their country in the largest degree it will admit of, and introducing among them the more civilized arts and customs, may be submitted to consideration.

(...)

But it is to be feared that, while the slaving trade with these people continues to be the great object of the Europeans, it will ever spirit up wars and hostilities among the negro princes and chiefs, for the sake of making captives of each other for sale. This, therefore, will ever obstruct the civilizing of these people, and 
extending of the trade into the bowels of Africa, which, by the contrary means, might be easily practicable.

Although somewhat patronizing, in this text Postlethwayt proves that he has a fairly good idea of the very negative consequences which the European colonialist policy and interference in Africa had for this continent. It seems that the author has come under the influence of the epoch's growing ideas of freedom and human rights which a few decades later were expressed in the American Declaration of Independence and the French Declaration of the Rights of Man and of the Citizen. However, in spite of the great advance that these general declarations represented at the ideological level, strong economic interest in both countries prevented them from leading to the immediate abolishment of slavery. Against this background, Postlethwayt once more stands before us as a child of the contradictory ideas and practice existing in his lifetime.

\section{Conclusions}

Within present-day lexicographical circles it is frequently claimed that lexicography should be considered a sub-discipline of linguistics, a sort of "applied linguistics". Although it cannot be denied that linguistics has played an important role in the compilation of a large number of dictionaries, Postlethwayt's Universal Dictionary of Trade and Commerce is an example of a dictionary to the production of which no specialized linguistic knowledge was needed or used. The author himself was an economist, just like the authors of a whole range of economic dictionaries produced in Europe during the last three centuries, cf. Besomi (2011). However, until now none of these authors have claimed that lexicography should be considered a sub-discipline of economics, a sort of "applied economics"; and it is not difficult to predict how they would react if they were told that they had been "applying" linguistics theories. What Postlethwayt's Universal Dictionary shows, is, on the one hand, that lexicography has a great interdisciplinary vocation, and, on the other hand, that the essence of lexicography should be found in the elements that are common to all lexicographical works, i.e. the core elements remaining when an abstraction is made from all the specific types of knowledge needed to compile specific dictionaries, cf. Tarp (2009).

As already stated, the specific knowledge reflected in the dictionary is, as a rule, completely outdated and only interesting from a historical perspective. The really intriguing aspect is how the author tries to meet the users' needs with a great variety of lexicographical data. In the fourth edition he informs us that he has received many letters with positive response to the previous editions. This suggests that he had a fairly good knowledge of his target users and their needs, and that it is exactly these complex needs which he tried to meet with the various types of data and the various "styles" and structures found in the dictionary. In a certain sense, Postlethwayt's dictionary is a structural and stylistic mess. Although modern lexicography could certainly improve the 
access to the relevant data, there seems to be a reason for this mess. The dictionary does not only provide information for cognitive needs, but also for operative ones. In some aspects it appears like a text book, at other times it is discussing, even putting in doubt former statements. It contains a big variety of up-to-date knowledge of that epoch, a "huge storehouse", not only of "economic facts, laws and theory", but also of practical "suggestions and intimations", all of these designed to meet the real needs and demands of his mideighteenth century's audience. In this respect, the Dutch specialist in the history of economics, Peter Groenewegen (2004: 1000), writes in his biographical article on Postlethwayt that the dictionary:

therefore contained many practical articles on inventions and improvements, as well as on commercial practice such as banking, commercial bills, and customs house business, hence catering for the considerable interest in compendia of knowledge of the mid-eighteenth century. The last enthusiasm was also evident in Postlethwayt's proposal for a remodelled Royal Society to enable it to collect information useful to British trade as well as to recommend new manufactures and new avenues of trade for official encouragement and support.

At a moment when traditional dictionaries are experiencing the start of a crisis owing to the fact that a growing number of potential users tend to satisfy their information needs by other means, most frequently on the Internet, modern lexicography can without any doubt learn much from dictionaries published in the Age of Enlightenment where the authors, like Postlethwayt, were not afraid of putting into their works exactly the types of data demanded and needed by their potential users. Today, with the advent of the computer and information technologies, especially the Internet, lexicographers should let themselves be inspired by past experiences and develop integrated information tools which may meet the complex needs of modern society whether these needs are of a communicative, cognitive, operative or interpretive art.

\section{Acknowledgements}

Thanks to the University of Valladolid, Spain, for allowing me to do research at the Biblioteca Histórica de Santa Cruz. Special thanks to Professor Pedro A. Fuertes-Olivera for arranging my visit to this marvellous library which contains about 18,000 books written between 970 and 1815, among them various old and rare dictionaries like the ones compiled by Postlethwayt and Savary des Bruslon.

\section{Literature}

Besomi, Daniele (Ed.). 2011. Crises and Cycles in Economic Dictionaries and Encyclopaedias. London/New York: Routledge.

Cantillon, Richard. 1755. Essai sur la nature de commerce en général. London: Fletcher Gyles. 
Chalmers, Alexander (Ed.). 1816. The General Biographical Dictionary: Containing an Historical and Critical Account of the Lives and Writings of Most Eminent Persons in Every Nation; Particularly the British and the Irish; from the Earliest Accounts to the Present Time. Vol. XXV. London: J. Nichols and Son.

Cowie, A.P. (Ed.). 2009. The Oxford History of English Lexicography. Volume II: Specialized Dictionaries. Oxford: Oxford University Press.

Groenewegen, Peter. 2004. Postlethwayt, Malachy (c. 1707-1767). Mathew, H.C.G. and Brian Harrison (Eds.). 2004. Oxford Dictionary of National Biography. Vol. 44: 999-1000. New York: Oxford University Press.

Hewins, William Albert Samuel. 1895. Postlethwayt, Malachy. Dictionary of National Biography. Vol. 46. London: Smith, Elder \& Co.

Johnson, Edgar Augustus Jerome. 1965. Predecessors of Adam Smith: The Growth of British Economic Thought. New York: A.M. Kelley.

Kaufmann, Uwe and Henning Bergenholtz (Eds.). 1998. Encyclopedic Dictionary of Gene Technology. English-Spanish. Toronto: Lugus Libros LatinAmerica Inc.

Leroyer, Patrick. 2012. From Subject-Based to User-Based Dictionaries: Rejecting the Cultural Opposition Thesis in Specialized Lexicography. Paper presented at the Seventeenth International Conference of the African Association for Lexicography, held at the University of Pretoria, Pretoria, 2-5 July 2012.

Mankin, Robert. 2008. Pins and Needles. Adam Smith and the Sources of the Encyclopédie. Brown, Vivienne (Ed.). 2008. The Adam Smith Review 4: 181-205. Oxford: Routledge.

Marx, Karl. 1867. Das Kapital. Kritik der politischen Oekonomie. Erster Band. Hamburg: Verlag von Otto Meissner.

Postlethwayt, Malachy. 1745. The African Trade, the Great Pillar and Support of the British Plantation Trade in America. London: J. Robinson.

Postlethwayt, Malachy. 1749. A Dissertation on the Plan, Use, and Importance, of the Universal Dictionary of Trade and Commerce; Translated from the French of the Late Celebrated Mons. Savary, Inspector-General of the Manufactures of the Custom-House of Paris: With such Considerable Additions and Improvements, As will Appear at Large Throughout this Dissertation; And which More Particularly Accommodate the Fame to the Trade and Navigation of the British Empire, Addressed to the Nobility, Gentry, Merchants, and Traders of Great Britain. London: John and Paul Knapton.

Postlethwayt, Malachy. 1751-1755. The Universal Dictionary of Trade and Commerce: Translated from the French of the Late Celebrated Mons. Savary, Inspector-General of the Manufactures of the Custom-House of Paris: With Large Additions and Improvements Incorporated throughout the Whole Work; Which More Particularly Accommodate the Fame to the Trade and Navigation of these Kingdoms; and the Laws, Customs, and Usages to which All Traders are Subject. London: John and Paul Knapton.

Postlethwayt, Malachy. 1774. The Universal Dictionary of Trade and Commerce: With Large Additions and Improvements, Adapting the Same to the Present State of British Affairs in America, Since the Last Treaty of Peace Made in the Year 1763. With Great Variety of New Remarks and Illustrations Incorporated throughout the Whole: Together with Everything Essential that is Contained in Savary's Dictionary: Also, All the Material Laws of Trade and Navigation Relating to these Kingdoms, and the Customs and Usages to which All Traders are Subject. The Fourth Edition. London: W. Strahan, J. and F. Rivington, J. Hinton. 
Savary des Bruslons, Jacques. 1723. Dictionnaire universel de commerce: contenant tout ce qui concerne le commerce qui se fait dans les quatre parties du monde, par terre, par mer, de proche en proche, et par des voyages de long cours, tant en gros qu'en dètail. Ouvrage posthume du Sieur Jacques Savary Des Bruslons. Continué sur les Memoires de l'auteur, et donné au public par M. Philemon Louis Savary. Paris: Chez J. Estienne.

Smith, Adam 1776. An Inquiry into the Nature and Causes of the Wealth of Nations. London: W. Strahan and T. Cadell.

Tarp, Sven. 2008. Revival of a Dusty Old Profession. Hermes. Journal of Linguistics 41: 175-188.

Tarp, Sven. 2009. Beyond Lexicography: New Visions and Challenges in the Information Age. Bergenholtz, Henning, Sandro Nielsen and Sven Tarp (Eds.). 2009. Lexicography at a Crossroads: Dictionaries and Encyclopedias Today, Lexicographical Tools Tomorrow: 17-32. Linguistic Insights. Studies in Language and Communication 90. Bern: Peter Lang.

Xie, Jin (Ed.). 1408. Yongle Dadian. Vol. 1-11,095. China. 